\title{
BREAKING THE CONSENSUS: \\ THE POLITICISATION OF MAORI AFFAIRS
}

Keith Barber

\begin{abstract}
This article takes issue with the claim made by Tremewan (2005a) that the New Zealand social sciences have been uncritical of neotraditionalist and culturalist trends in social policy. It points out that at least since the 1980 s there has existed a significant body of social science literature critical of these trends. The article also takes issue with Tremewan's attribution of increased political dissent in the area of Maori affairs to the culturalist ideological currents dominating social policy. The article provides an alternative explanation for this increase in political dissent by focusing upon the material conditions of existence and the opportunism of power-seeking politicians.
\end{abstract}

\section{INTRODUCTION}

In his article 'Ideological Conformity: A Fundamental Challenge to the Social Sciences in New Zealand', Tremewan (2005a) asks the question why has there been such 'a welling-up of unexpressed political dissent' in the area of Maori affairs in recent years 'that it was available for political mobilisation' by the National Party in the lead-up to the 2005 parliamentary elections (p.1). His answer is that an extreme form of culturalism has become embedded in New Zealand social policy and this has alienated large sections of the population. He also takes up the concern of Elizabeth Rata (2000), that there has arisen in New Zealand a neotribal elite who, by calculated political leverage of the opportunities afforded by the marriage of culturalist ideology and neoliberalism, have gained control of Treaty of Waitangi grievance settlements, and have brokered a non-democratic neo-traditionalist ideology into the institutions of the democratic state. But the main objective of Tremewan's paper is to ask why the social sciences have been complicit in these developments (p.9) - why they have been active in supporting the culturalist social policy agenda? - and he calls for a more critical social science. 
The question of why there has been a rise in the level of public dissent in recent years over government handling of Maori affairs is an important one, and I will return to it in the second part of this paper. But first I would like to take issue with the claim that the New Zealand social sciences have been uncritical of neo-traditionalist ideology and culturalist social policy.

\section{IDEOLOGICAL CONFORMITY?}

I welcome Tremewan's call for a critical social science, and have always tried to work within that tradition myself. When I was a graduate student at Auckland University in the 1970s I found myself attracted to the Frankfurt School of critical theorists, and adopted the insights of one it its members, Jurgen Habermas, in my $\mathrm{PhD}$ thesis (Barber 1986). I took as my point of departure, Habermas' warnings about the consequences of the administrative appropriation of culture:

Cultural traditions have their own vulnerable conditions of reproduction. They remain 'living' as long as they take shape in an unplanned, nature-like manner, or are shaped with [reflective or critical] consciousness ... In both cases appropriated cultural contents retain their imperative force, that is, they guarantee the continuity of a history through which individuals and groups can identify with themselves and with one another. A cultural tradition loses precisely this force as soon as it is objectivistically prepared and strategically employed. In both cases conditions for the reproduction of cultural traditions are damaged, and the tradition is undermined. This can be seen in the museum-effect of a hedonistic historicism, as well as in the wear and tear that results from the exploitation of cultural contents for administrative or market purposes. (Habermas 1976:70-71)

In my $\mathrm{PhD}$ thesis I argued that the administrative appropriation of Maori culture under the government's policies of 'biculturalism' and 'devolution' would produce just this sort of wear and tear, and I tried to demonstrate this in a study of central government, local body, and Maori community cooperation in the area of employment creation. I remember being told by one of the gatekeepers of social science research funding at the time that if I persisted with this line of inquiry I would never get any research funds, and, what is more, my thesis would never be passed. But I did persist (without research funds) and the thesis was passed, and one or two people may even have read it. 
Later, Jeff Sissons (1993), in describing 'the systemic use of Maori tradition' in New Zealand during the 1970 s and 1980s, argued that Maori language, marae, hui ceremony, beliefs and values had been 'selectively appropriated' by the state to enhance Maori identity and self-esteem, and improve social integration, Maori self-administration, and state legitimacy. The result, he said, was 'a fragmentation, objectification and standardisation of form and meaning' in which Maori tradition appeared as 'an awkward, distorted simulation of 'the real" (p.113). But the most concerted critique of biculturalism in recent years has been that of Elizabeth Rata (2000). Her critique differed from that of mine in that, whereas I focused on the government's administrative appropriation of Maori culture, she gave far greater weight to the agency of Maori in the construction of the bicultural relationship. I appear to have underestimated the bureaucratic and capitalistic ambitions of the rising Maori middle-class and naively interpreted Maori culture as essentially non-capitalistic. Steven Webster at the time said that I was too 'culturalist' in my approach (personal communication).

Elsewhere (Barber 1989) I discussed the 'administrative appropriation of culture' in the context of contemporary capitalism, with its tendency to absorb increasing quantities of not only economic but also socio-cultural resources in its effort to sustain its crisis-ridden path of development. There I made the prediction that future conflicts in New Zealand 'race relations' would be over the utilization of resources devolved to Maori organization via the Waitangi Tribunal. I had in mind that pressure would be brought to bear upon Maori organizations to utilize these resources in a capitalist way, and that this would contradict the non-capitalist values of Maori society. What I hadn't envisaged was that the pressure to utilize these resources capitalistically would come from within Maori society itself, and that the conflicts would be between different groups of Maori (see the discussion of the distribution of Fisheries Assets below).

After 1989 I ceased to focus on things Maori. For one reason, a growing number of Maori researchers were making research and commentary on Maori issues by non-Maori clearly unwelcome (Tremewan [2005:10] refers to this sort of pressure as 'intellectual intimidation'). But also I wanted to extend my ethnographic horizons. So for the next ten years I focused my research activity on Papua New Guinea. I continued, however, to be interested in ethnic politics, and I read with interest what others were writing about it in New Zealand. And much of it seemed to be very critical of what Tremewan, in his article, calls 'neo-traditionalism' $(2005: 4,12)$. 
For example, in the 1980 os one of the important issues in anthropology was the 'politics of tradition' - the thesis that custom and tradition can be manipulated to legitimise chiefly and other inegalitarian forms of polity (Keesing and Tonkinson 1982, Keesing 1989; Hobsbawm and Ranger 1983). In 1990 Mike Goldsmith, at Waikato University, organized a conference of the New Zealand Association of Social Anthropologists on 'The Politics of Interpretation'. The keynote speaker was Roger Keesing (1992), one of the luminaries in the 'politics of tradition' debate, and a number of papers presented at that conference addressed this issue.

Shortly before the conference, a controversy had broken out involving the American cultural anthropologist Alan Hanson (1989) who had offended some New Zealand anthropologists with his depiction of Maori culture as 'invented'. In the climate of growing Pakeha distrust of some Maori claims to cultural authenticity, Hanson's depiction was seen as reckless, particularly as it was picked up and sensationalised by the New Zealand media. And some New Zealand anthropologists wanted him chastised. My own contribution to this debate was to try and shift the blame, from Hanson the individual onto the culturalist framework within which he worked, and from which the offending statements seemed to me to logically derive. (I felt that some of those seeking to chastise Hanson were engaged in much the same theoretical project as him). I am grateful to Steven Webster for preserving my contribution to this debate in his own much broader discussion of this issue:

Do we need to attribute the unwelcome interpretations of Hanson's work to his own thoughtlessness, incaution, or even mischievousness? Or could such consequences be seen as flowing predictably out of the theoretical tradition in which he writes? When for example, both cultural invention and ordinary everyday social reproduction are seen, as they are by Hanson, in terms of 'sign-substitution in a play of signification' (p.898), and his own anthropological writings are seen in the same terms (p.899), is it any wonder that self-serving interpretations might be derived from it? And if the tradition in which he writes denies, as he claims, any solid foundation for truth and knowledge, then doesn't it also provide the licence to interpret things in any way one pleases? By the same token, doesn't it also deny any notion of responsibility for what is written? These are some of the sorts of questions that might be usefully addressed to Hanson's theoretical approach and to some of the other approaches in anthropology that go under the broad heading of 'interpretive'. (Barber 1990, cited in Webster 1998: 235). 
My purpose in recounting these events today has been to point out that at least since the 1980s, New Zealand anthropologists have been critically discussing culturalism and neo-traditionalism in New Zealand ethnic politics. But by way of further illustration of this fact, I will summarise below some of the more readily accessible writings in this area. For convenience of presentation I have organised them under a number of headings describing their main empirical focii: Fisheries Assets, Cultural Nationalism, and Devolution.

\section{FISHERIES ASSETS}

In 1992, the government transferred to a group of government appointed commissioners commercial fisheries assets for distribution to iwi in return for the relinquishing of claims to fisheries under the Treaty of Waitangi. One of the controversial issues to emerge from this deal was how iwi (the recipients of shares in the assets) were to be defined. As Levine (2002) has pointed out, it was a state appointed authority, the Treaty of Waitangi Fisheries Commission, that was called upon to decide what an iwi was, and when Urban Maori Authorities - equally nontraditional organizations - disputed their definition, it was the Court, a state institution, that had the final say (p.77-79). What was at issue in this dispute was which form of contemporary Maori organization, Tribal Trust Boards or Urban Maori Authorities, was more 'traditional'. But the point of Levine's discussion is that whatever way you looked at it, it was State institutions that were deciding the answer. Cheater and Hopa (1997) had also pointed out the role of the State in constructing Maori and iwi identities in their earlier discussion of this and other issues.

It also had been pointed out that there was more at issue in this State driven process of identity construction than that of mere 'cultural authenticity'; there was the class interests of the parties behind the contending definitions. As Levine put it

Although all the principals in the iwi debate are Maori, the class interests represented by the Commission and umas [Urban Maori Authorities] are clearly divergent. Urban Maori unaffiliated with tribes tend to be less affluent than the iwi fundamentalists. The directors of the Treaty of Waitangi Fisheries Commission maintain close links with government and some have been knighted, while those who run UMAs can boast street credibility. The Commissioners subscribe to a big-business, anti-welfare, model of Maori development, while the unemployed or working class person wants to see the assets doing something directly for them. (p.81) 
In anthropological terms, what was at play here was the 'politics of tradition', just that in this case it was Fisheries Commissioners rather than tribal chiefs or custom leaders who were appealing to 'tradition' to mask their class interests (p.81). Webster (2002), in his discussion of these events, viewed the struggle slightly differently from Levine. Webster saw it as a struggle between two 'new Maori elites' (the Fisheries Commissioners and the Urban Maori Authority chief executives), both of whom had been drawn into the net of restructured capitalism, while 'the poor majority of rural and urban Maori' watched 'sceptically from the sidelines' (p.371).

If it is not already clear, the point I am trying to make by revisiting this issue is that all of these anthropologists, Levine, Cheater, Hopa and Webster, regardless of their slight differences of interpretation, were unequivocal in their attribution of material interests to the parties involved in the dispute, and they were all equally dismissive of the culturalist perspective. The same can be said for most other anthropological or sociological studies of ethnic politics in New Zealand during the 1990 .

\section{CULTURAL NATIONALISM}

As early as 1984, Hauraki Greenland had produced a penetrating analysis of the Maori protest movement in which he detailed the politicisation of Maori cultural symbols in their idealist critique of Pakeha domination. In 1996, Poata-Smith brought this form of analysis up to date in a critical examination of the ideological assumption and political effectiveness of 'cultural nationalism' as a strategy for Maori liberation. Poata-Smith traced the origin of the Maori protest movement to the struggle to win Maori studies and Maori language programmes in the education system, and he argued that for a large section of the movement an emphasis on the rediscovery of culture came to be the objective, rather than political struggle. With its emphasis on lifestyle change, the movement presented no threat to the State, and was easily accommodated by the State policies of the 1980 os (pp.106-7). This accommodation, Poata-Smith says, resulted in a dramatic expansion of employment opportunities for middle-class professional Maori, but it provided no benefits for the vast majority of working-class Maori bearing the brunt of the 199os economic restructuring. In the final analysis, Poata-Smith saw 'cultural nationalism' as having failed as a strategy for Maori liberation; first, because it lacked attention to the issues of class, it failed to take into account the working-class location of the majority of Maori; and second, because of its culturalism, it was unable to form strategic alliances with other progressive movements of the time (p.111). Once again, as we saw with the analyses of the fisheries assets dis- 
tribution process, analytical attention was given to the issue of material class interests, with an accompanying political critique of culturalism.

\section{DEVOLUTION}

'Devolution' was the name given to the policy beginning in the 1980s whereby the government sought to shift social welfare responsibilities for Maori clients onto Maori organizations. As Barcham (1998) demonstrated, the iwi organizations targeted by this policy were required to pass stringent government accountability standards, with the outcome that the 'dynamic character of Tikanga Maori ... [was] lost' (p.306). Roger Maaka (1994) arrived at a similar conclusion in his study of the formal retribalization of an urban Maori group in Christchurch to fit it for the delivery of government-funded welfare programmes. He argued that the process was hampered by government policies that 'attempt to freeze-dry the tribe, and indeed Maori culture as a whole, at an arbitrary point in time that ignores the fact that social grouping is a process' (p.314). He concluded that

the notion of the tribe-cum-nation as an expression of mana Maori motuhake 'Maori sovereignty' is more an ideology of the politically active and the educated elite than a reality for the flax roots of Maori society. The issue cannot be seen in terms of a simple opposition between tribal social organization and pan-Maori groupings; retribalization in the 1990s, if it is to be effective, requires a radical redefinition of tribe rather than the revitalization of a traditional sociopolitical grouping. Membership of the new tribe will need to be defined by association, commitment, and domiciliary location rather than by descent alone (p.329)

Both of these accounts of the devolution process reiterate the position that contemporary forms of Maori social organization are far from traditional. They also, if I may say, bear out the predictions that I had made earlier in my $\mathrm{PhD}$ thesis, following Habermas' comments on the corrosive effect of the administrative appropriation of culture.

\section{PATRONS OF MAORI CULTURE}

The most concerted attack upon the culturalist paradigm in New Zealand anthropology has been that of Steven Webster. In his book Patrons of Maori Culture (1998), Webster set out to deliberately counter culturalist interpretations of the situation of Maori culture in New Zealand. He examines the contempo- 
rary situation of Maori and argues that an idealist anthropological preconception of culture has obscured the real situation as it has emerged from colonial and recent history. The real situation, he says, shows that the 'beneficiaries of the cultural 'renaissance' may be more its opportunistic patrons, Maori as well as Pakeha, than the majority of Maori themselves.' (p.19). He traced the roots of the idealist conception of Maori culture to the 1920s, when, he says, it was developed as one more acceptable to the sensitivities and fears of the bourgeoisie than the actual culture that was emerging in the behaviour of working-class Maori. He sees the contemporary image of Maori culture that has been developed during the recent Maori renaissance as performing the same ideological functions. And Webster attributes the idealist obfuscation of Maori culture to the emergence of post-structural and postmodernist theories in the late 1980 s.

Do I need to say more? My objective here has been to point out that there does exist a significant body of social science literature in New Zealand that has been critical of neo-traditionalism in New Zealand ethnic politics, and of culturalist theory. Sometimes the criticism of culturalism is implicit, in that a preferred approach (usually with a political economy bent) has been adopted; sometimes (as with Poata-Smith and Webster) the critique is explicit. Further examples can and have been given by others (for example Sissons 2005, Ryan 2005).

I will return now to the more important question of why there has been a rise in recent years in the level of public dissent over the government's handling of Maori affairs.

\section{THE POLITICISATION OF MAORI AFFAIRS}

Tremewan $(2005 a, b)$ canvases a number of 'partial' explanations for this. He refers to a generalised public unease over Waitangi Treaty claims, responsibility for the redressing of historical wrongs, and the ethnic assertiveness of 'born again Maori', but he gives priority to the culturalist ideological currents dominating social policy, and confines his analysis to the reasons why the social sciences have failed to critique these. As I have demonstrated above, I do not think that his charge of social science complicity in a culturalist ideological hegemony holds up. Furthermore I do not believe that it is sufficient to confine causal analysis of socio-political developments to the level of ideology. To better understand the recent politicisation of Maori affairs we need to take a wider perspective. 
We can take the same starting point as Tremewan, the speech given by the National Party leader, Don Brash, in January 2004 (Brash 2004). This speech was essentially an attack upon the constitutional status of Maori (as the indigenous people of New Zealand), as secured by the Treaty of Waitangi. In it the idea that the Treaty had created a partnership between Maori and the Crown was explicitly denied, and three issues came in for special criticism: 1) government funding based on race; 2) the extension to local authorities of special provisions for Maori representation; and 3) the existence of legislative provisions under the Resource Management Act for special consultation with Maori. Here is the passage concerned:

There can be no basis for special privileges for any race, no basis for government funding based on race, no basis for introducing Maori wards in local authority elections, and no obligation for local governments to consult Maori in preference to other New Zealanders.

In Brash's own words, the overall message of the speech was that 'The Treaty of Waitangi should not be used as a basis for giving greater civil, political or democratic rights to any particular ethnic group. The significance of this speech is that it was immediately followed by an upsurge in public support for the National Party.

Some indication of the mindset to which the Brash speech appealed was given by a public opinion poll and street survey that was conducted by the New Zealand Herald (2004a) three weeks later. In the public opinion poll, 642 non-Maori New Zealanders were asked whether they supported the National Party's 'proposal to remove racial distinctions from Government services'. Seventy-five percent of respondents said they did. But when they were asked in what areas did such racial distinctions occur, 36 percent could not answer, and those who did named special Maori health and education services, both of which Don Brash had said in his speech a National government would continue. There was a clear discrepancy between what was said in the speech and what the public were expressing support for. Another curiosity was that despite the widespread opposition to 'race based funding', 87 percent of those opposed to it said that it had little or no affect on them.

A clearer indication of the depth of feeling among the Pakeha public was gained from a survey of 150 people conducted on the same day as the opinion poll (New Zealand Herald 2004b). A substantial majority believed that government funding should be based on need, not race. They believed that Maori received help that others were not entitled to; that this help had gone 
too far; that the country could not endlessly make up for the wrongs of the past; and that the help given to Maori was too easily abused. But although most believed Maori got special assistance, they struggled to be specific as to where Government spending based on race actually occurred. Education and health again stood out in their attempt to name some areas. But, as we have seen, these were the areas which the National Party said they would continue to fund. Most survey respondents simply said they were opposed to special treatment for Maori on principle.

When questioned about the Treaty of Waitangi there was broad support among survey respondents for an end to compensation payments. People complained that there seemed to be no end in sight; that payments were misspent and that new claims kept emerging. Common assertions were: 'It's got out of control'; 'It's gone too far'; 'There seems to be no end to it.' These claims were coupled with the view that special funding and treaty settlement money was misspent: 'They want payouts all the time but what they do with it is piss it up against the wall'; 'They just seem to go through the money. All those millions that go missing - it's just not on'; 'I think the Government is throwing all this money down a never-ending pit'. There was no shortage of outrage. But like the poll respondents, few of those questioned in the survey could pinpoint any way that they personally had been affected by special treatment for Maori. Many, however, feared for the future: 'We could lose a lot of what we've got now - land, beaches - and it will affect the economy', they said.

In my experience, anti-Maori attitudes such as these are endemic among Pakeha New Zealanders. But they have changed over time. When Maori were perceived as a marginalized and disadvantaged group, anti-Maori attitudes usually took the form of paternalistic assimilationism. There was a general willingness amongst Pakeha to help Maori become more like them, and few objections were ever voiced to dedicating funds to this effect. But recently, since some Maori groups and individuals have become the beneficiaries of Treaty of Waitangi settlements, Maori as a whole have come to be perceived as a privileged group, and for most Pakeha the idea that an already privileged group should be receiving further special assistance is anathema. As a result, a high level of anti-Maori resentment has emerged. In my analysis, this resentment has emerged from the conflation of two different but related issues: 'ethnically targeted social spending' and 'treaty claims'.

'Ethnically targeted social spending' is a form of positive discrimination (or affirmative action) that is aimed at overcoming Maori social disadvantage; 'treaty claims', on the other hand, is a constitutional process whereby Maori 
organisations are able to make claims upon the State for compensation for historical breaches of the Treaty of Waitangi. The two issues could be considered separately. One is a matter of social welfare; the other is a constitutional issue. But in the popular imagination they have become conflated and as a result Maori have come to be seen as doubly privileged. 'Ethnically targeted social spending', as a form of positive discrimination, is seen as contradictory to 'treaty claims' that endow Maori with special privileges.

This conflation of issues has raised the level of Pakeha resentment toward Maori, and that resentment provided the National Party with the opportunity of attracting a wider political following. The issue of 'treaty claims' has long incurred the resentment of wealthy resource developers, one of National's traditional constituencies, who see such claims as giving Maori privileged access to and control over lucrative natural resources. 'Ethnically targeted social spending', on the other hand, incurs the resentment of ordinary working class New Zealanders, who see their Maori neighbours as enjoying privileged access to increasingly scarce social services. Through the conflation of these two issues, resentment toward Maori has become heightened, and broadened, and able to be worked up into a populist basis for unifying the two ends of the New Zealand class spectrum, gifting the National Party with the means of gaining working-class support for its business oriented and anti-worker 'neo-liberal' agenda.

To more fully explain the rise of anti-Maori sentiment a number of additional factors need to be considered. Here they can be touched upon only briefly. I have made much so far of the conflation of 'ethnically targeted social spending' and 'treaty claims'. These two issues could be considered separately, but from the beginning successive governments have always considered them in tandem. Part of the rationale for 'treaty claims' has been to fund tribal organisations so they could take over from the State social welfare responsibility for their members. This could be described as the strategic or instrumental conflation of the two issues. In the public imagination, however, the conflation is more irrational and prejudicial. It arises out of a wide field of Pakeha ignorance of Maori society that leads to such common misconceptions as educational scholarships paid for out of tribal funds being seen as examples of 'race based government funding. This level of ignorance provides a wide field for the cynical promotion of a 'politics of resentment'.

Contributing further to the 'politics of resentment' has been the tendency for policy makers to separate the socio-economic problems of Maori from those affecting other New Zealand families and communities. This separation re- 
sults from seeing the economic problems of Maori solely in terms of ethnicity. In this way they are isolated and viewed as requiring specific 'Maori only' solutions. The present Labour led Government embarked upon this path at the being of its first term of office with its 'Closing the Gaps' policy. Then, in reaction to Pakeha resentment, and on the basis of research purporting to show that the gap in socio-economic status between Maori and Pakeha did not exist (Chapple 2000), it changed its policy to one of 'Reducing Inequalities' across the board. Alternative proposals by the ACT and National Parties define the problem of Maori disadvantage as one of individual moral shortcomings, and seek to deal with this through a policy of punitive welfare reforms. Both tendencies obscure the more fundamental causes of social disadvantage that can be found in the economic dislocations that have affected all New Zealand families and communities, regardless of ethnicity, and which stem from the restructuring of the economy to meet the conditions of global competition.

As in other parts of the world (Wilson 1999:490), national and international economic transformations since the mid-1980s have placed new stresses on New Zealand families and communities. For some, there has been a decline in real wages such that many working-class families are now barely able to maintain their living standards on two incomes; the length of the working week has increased, while job security has decreased; there has been an increase in the cost of education and health services, so that many parents today fear not being able to send their children to university, or not being able to pay for necessary health care. Given the shock of economic restructuring, economic anxiety pervades the society and lingers, despite temporary improvements in the economy. The recent upsurge in anti-Maori feeling, expressed in opposition to the 'treaty rights' and 'race-based funding' can be related to these feelings of economic insecurity.

Studies of ethnic conflict around the world have shown that rises in ethnic antagonism are often related to rises in feelings of economic anxiety. During such times people become receptive to simplistic ideological messages that deflect attention away from the real complex causes of their problems and onto vulnerable groups. Ethnic minorities, immigrants and welfare beneficiaries are the normal targets of such antagonism. But this does not happen spontaneously. It takes highly visible spokespeople to channel peoples' frustrations in this direction (Wilson 1999:495), and we have seen recent examples of this in New Zealand. There is the example of NZ First's attacks upon non-European immigrants. There is the АСт Party's persistent denigration of welfare beneficiaries. Now the National Party has adopted the same strategy 
in its attacks upon Maori. It is primarily a vote gathering, constituency-building exercise that appeals to the worst features of human nature.

Finally there is the influence of neo-liberal ideology upon peoples' understandings of social processes and its attachment to the idea of 'race'. As is well known, neo-liberalism is averse to the idea of society as a constellation of social groups. To the neo-liberal, society is a constellation of individuals. In neo-liberal ideology there is no place for the concepts of 'culture', 'ethnicity', or 'indigeneity', in so far as these concepts are inextricably linked to the notion of social groups. 'Race', on the other hand, despite the fact that it is a socially constructed identity, can be more easily understood as the property of individuals, in the sense that individuals can be identified on the basis of their bodily characteristics (e.g. skin colour). It is therefore easy to accommodate the idea of 'race' within neo-liberal ideology, where in accordance with notions of meritocracy it is criticised as a basis for discrimination. This might explain why neo-liberal apologists often express their opposition to ethnically targeted affirmative action in terms of the unjustifiable allocation of privileges on the basis of 'skin colour'. There seems to be an incapacity within neo-liberal ideology to accommodate the notion of group identities and to separate them from the characteristics of individuals, imputed or otherwise. As a result, rights and privileges that accrue to groups (whether they be 'cultural', 'ethnic' or 'indigenous') can only be conceived within neo-liberalism as accruing to individuals on the basis of their 'racial' characteristics. Within the confines of this narrow individualist ideology, and in the light of current proscriptions on racial discrimination, it is possible for neo-liberals to feel justified in opposing any form of ethnically targeted social spending or 'treaty rights' (Barber 2005).

\section{CONCLUSION}

Until 2004, a consensus existed in New Zealand politics between the two major political parties (Labour and National) with regard to Maori affairs. This consensus was expressed in terms of a shared commitment to 'biculturalism' (the official recognition of Maori cultural values and their incorporation into official public discourse and policy considerations). It was from this commitment that the National Party has been trying to resile. By building on a groundswell of Pakeha resentment toward Maori, it aimed to differentiate itself from Labour and attract electoral support. The important question is why had there been such a rise in the level of public dissent in recent years over government handling of Maori affairs that this political option had become 
available? Tremewan (2005a,b) says that it is because a culturalist ideology dominates social policy and this has had an alienating effect on large sections of the population. I have argued that it is not sufficient to confine explanation of socio-political developments to the analysis of ideology in this way. A great many other factors, including the material conditions of existence, and the opportunism of power-seeking politicians, are involved. Even at the level of ideology, I would argue, it is not culturalism that is responsible for the politicisation of Maori affairs, but neo-liberalism.

\section{REFERENCES}

Barber, K. 1986 Employment and 'Race Relations' Policy in New Zealand: A Critique, unpublished $\mathrm{PhD}$ thesis, University of Auckland.

Barber, K.1989 New Zealand 'race relations' policy, 1970-1988, Sites 18:5-16.

Barber, K. 2005 Indigenous rights or 'racial privileges': The rhetoric of 'race' in New Zealand politics, European Society of Oceanists 6th Conference, 6-8 July 2005, Marseille, France.

Barcham, M. 1998 The challenge of urban Maori: reconciling conceptions of indigeneity and social change, Asia Pacific Viewpoint 39 (3):303-314.

Brash, D. 2004 Nationhood - An address by Don Brash, Leader of the National party, to the Orewa Rotary Club. The New Zealand Herald, January 28.

Chapple, S. 2000 'Maori Socio-Economic Disparity' Political Science, 52 (2):101115.

Cheater A. and Hopa, N. 1997 Representing identity. In James, A., Hockey, J. and Dawson, A. (eds) After Writing Culture: Epistemology and Praxis in Contemporary Anthropology, London: Routledge.

Goldsmith, M. and Barber, K. (eds) 1992 Other Sites: Social Anthropology and the Politics of Interpretation, Palmerston North, Massey University.

Greenland, H. 1984. Ethnicity as ideology: A Critique of Pakeha Society. In P. Spoonley, C. Macpherson, D. Pearson and C. Sedgwick (eds), Tauiwi: Racism and Ethnicity in New Zealand, pp. 86-102. Palmerston North: Dunmore. 
Habermas, J. 1976 Legitimation Crisis, London: Heineman.

Hanson, A. 1989 The making of the Maori: cultural invention and its logic, American Anthropologist, 91: 890-902.

Hobsbawm, E. and Ranger, T. (eds) 1983 The Invention of Tradition, Cambridge: Cambridge University Press.

Keesing, R. 1989 Creating the Past: Custom and Identity in the Contemporary Pacific, The Contemporary Pacific, 1 (1\&2):19-42.

Keesing, R. 1992 The past in the Present: contesting representation of culture and history. In Goldsmith, M. and Barber, K. (eds) 1992 Other Sites: Social Anthropology and the Politics of Interpretation, Palmerston North, Massey University, pp. 8-28.

Keesing, R. and Tonkinson, R. (eds) 1982 Reinventing Traditional Culture: The Politics of Kastom in Island Melanesia, Mankind, (Special Issue) 13 (4).

Levine, H. B. 2002 The Maori iwi - contested meanings in contemporary Aotearoa/New Zealand. In Kolig and Muckler (eds) Politics of Indigeneity in the South Pacific, Munster: Lit Verlag.

Maaka, R. 1994 The New Tribe: Conflicts and Continuities in the Social Organization of Urban Maori. The Contemporary Pacific (6):311-336.

New Zealand Herald, 2004a What's eating Pakeha, 21 February.

New Zealand Herald, 2004b What's eating Pakeha. The verdict from the street. 21 February

Poata-Smith, Evan S. Te Ahu 1996. He Pokeke Uenuku i Tu Ai, The Evolution of Contemporary Maori Protest, Nga Patai: Racism and Ethnic Relations in Aotearoa/ New Zealand, Spoonley, Pearson and Macpherson (eds) Palmerston North: Dunmore.

Rata, E. 2000 A Political Economy of Neotribal Capitalism, Lanham:Lexington Books. 
Ryan, T. 2005 Goodies-and Baddies? On Christopher Tremewan's Ideological Conformity: A Fundamental Challenge to the Social Sciences in New Zealand. Sites, New Series 2 (1):33-37.

Sissons, J. 1993 The Systemation of Tradition: Maori Culture as a Strategic Resource, Oceania 64 (2): 97-116.

Sissons, J. 2005 Beware the Maori Elite? A reply to Christopher Tremewan's Ideological Conformity: A Fundamental Challenge to the Social Sciences in New Zealand. Sites, New Series 2 (1):28-32.

Tremewan, C. 2005a Ideological Conformity: A Fundamental Challenge to the Social Sciences in New Zealand, Sites, New Series 2 (1):1-27.

Tremewan, C. 2005b It's Time to Answer the Important Questions - A response to Sissons and Ryan, Sites, New Series 2 (1):38-44.

Webster, S. 1998 Patrons of Maori Culture, Theory and Ideology in the Maori Renaissance, Dunedin: Otago University Press.

Webster, S. 2002 Maori Retribalization and Treaty Rights to the New Zealand Fisheries, The Contemporary Pacific, 14 (2):341-376.

Wilson, J.W. 1999 When work disappears: new implications for race and urban poverty in the global economy, Ethnic and Racial Studies, 22 (3):479-499. 